\title{
Studies on Polish endemic species - vascular plants. \\ 1. Gladiolus felicis Mirek nom, novum (=G. parviflorus Berdau nom. illeg.)
}

\author{
ZBIGNIEW MIREK \\ Institute of Botany, Polish Academy of Sciences, Lubicz 46, 31-512 Kraków, Poland \\ (Received: July 20, 1984. Accepted: January 2, 1985)
}

\begin{abstract}
This study is on an endemic species of Polish flora, known until now as Gladiolus parviflorus Berdau (Iridaceae). Due to the existence of two earlier homonyms, a new species name for this taxon is proposed-Gladiolus felicis. The position, range and rank of this enigmatic taxon are discussed on the basis of biometric studies. The localization of all of its stands known until now is presented.
\end{abstract}

Key words: Gladiolus felicis, endemic species, taxonomy, nomenclature, Poland

\section{INTRODUCTION}

Gladiolus parviflorus, considered an endemic species of Polish flora, was described from Cracow and its vicinity by Berdau in 1859. In spite of the fact that Berdau (1859) emphasized that it is clearly distinct from other European species, this taxon gave rise to doubts from the beginning. Uncertainties concerning the actual distinction and status of $G$. parviflorus arose, among others, from the fact that this species was found as a rule together with specimens of G. imbricatus in stands in Cracow and in others discovered later. No geobotanical explanation was found either for the existence of a separate Gladiolus species in this part of Europe. For these reasons Polish botanists (see Szafer et al. 1953) considered this taxon as a critical one and emphasized the need for further, more precise studies on it. Shortly after $G$. parviflorus was described, foreign authors recognized it as conspecific with G. imbricatus L. (Nyman 1878-1882) and this opinion is held until the present (Hamilton 1980). From the time of Nyman's 
publication (1878-1882), in which the name of the species under study here was distorted into $G$. pauciflorus Berdau, the erroneous name of this taxon is found in European literature (see e.g. Index Kewensis 1895, Hamilt on 1980).

In this study, it was attempted to elucidate the position and taxonomic rank of $G$. parviflorus on the basis of comparative biometrical studies.

\section{MATERIAL AND METHODS}

In this study, the entire available $G$. parviflorus material was used, that is, about 80 herbarium specimens from two Cracow herbaria (abbreviated: KRA and KRAM according to Holmgren et al. 1981). For comparison, about 40 randomly selected specimens of $G$. imbricatus from different regions of the range of this species were also measured. The following characters were taken into account: flower length, flower tube length and shape, anther and stamen filament lengths, stigma length and ratio of anther to filament lengths. The individual flower parts were immersed in warm water and straightened before measuring. One flower from each specimen was measured. The variability of the studied material is presented in the form of scatter and frequency diagrams and compared in a Table 1.

Table 1

Major differences between Cladiolus felicis and G. imbricatus

\begin{tabular}{|c|c|c|c|}
\hline $\begin{array}{l}\text { Character } \\
\text { number }\end{array}$ & Character & G. felicis & G. imbricatus \\
\hline 1 & $\begin{array}{l}\text { flowers in the } \\
\text { inflorescence }\end{array}$ & $\begin{array}{l}\text { close to the inflorescence } \\
\text { axis }\end{array}$ & $\begin{array}{l}\text { bent away from the inflo- } \\
\text { rescence axis }\end{array}$ \\
\hline 2 & inflorescence & $\begin{array}{l}\text { many-sided or indistinctly } \\
\text { two-sided }\end{array}$ & clearly one-sided \\
\hline 3 & flower length, $\mathrm{mm}$ & $(15)-17-25-(27)$ & $(27)-30-38-(41)$ \\
\hline 4 & flower tube length, $\mathrm{mm}$ & $3-7.5$ & $7.5-9$ \\
\hline 5 & flower tube shape & straight (slightly curved) & clearly curved \\
\hline 6 & perianth color & $\begin{array}{l}\text { reddish-lilac on the edges, } \\
\text { yellowish-green in the } \\
\text { center }\end{array}$ & lilac \\
\hline 7 & $\begin{array}{l}\text { pistil style length (without } \\
\text { stigma), mm }\end{array}$ & $9-22$ & $23-30$ \\
\hline 8 & filament length, $\mathrm{mm}$ & $3-15$ & $(16)-17-20-(21)$ \\
\hline 9 & $\begin{array}{l}\text { ratio of anther to } \\
\text { filament lengths }\end{array}$ & $(0.5)-0.6-1.5-(2.2)$ & $0.4-0.6$ \\
\hline
\end{tabular}




\section{RESULTS}

GENERAL CONCLUSIONS

The results obtained confirmed Berdau's opinion (1859) about the outstanding separateness of $G$. parviflorus in relation to $G$. imbricatus (and also to other European species) and justify distinguishing it as a separate species. It has been found that the characteristics allowing certain discernment of $G$. parviflorus from $G$. imbricatus are: flower, pistil style and filament lengths (Figs. 1, 2, 3 and 4), and, to a lesser extent, the remaining studied traits (Table 1). The character accepted until now by Polish botanists (Kulczyński 1919, Szafer et al. 1953) as a key one, that is, the ratio of anther to filament lengths, has shown to be of little use in identification.

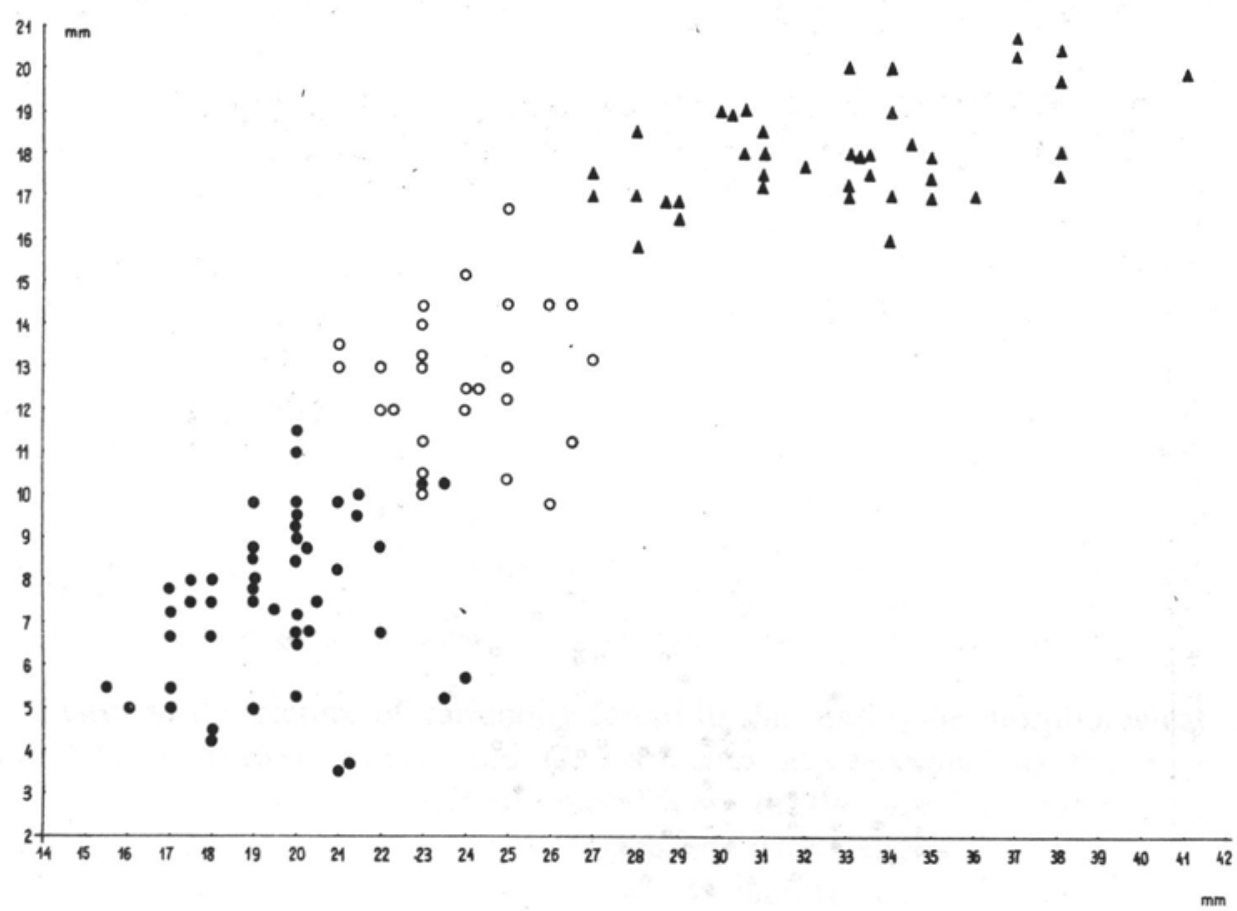

Fig. 1. Scatter diagram of the investigated specimens, based on length of filaments (vertical axis) and length of flowers (horizontal axis). 1 - Gladiolus felicis var. felicis; $2-G$. felicis var. żmudae; $3-$ G. imbricatus

NOMENCLATURE

Due to the existence of two earlier homonyms, that is, Gladiolus parviflorus Jacq. (1767, Observ. Bot. 2) and Gladiolus parviflorus Vahl (1804, Enum. plant. 1), the name Gladiolus parviflorus Berdau (1859) 


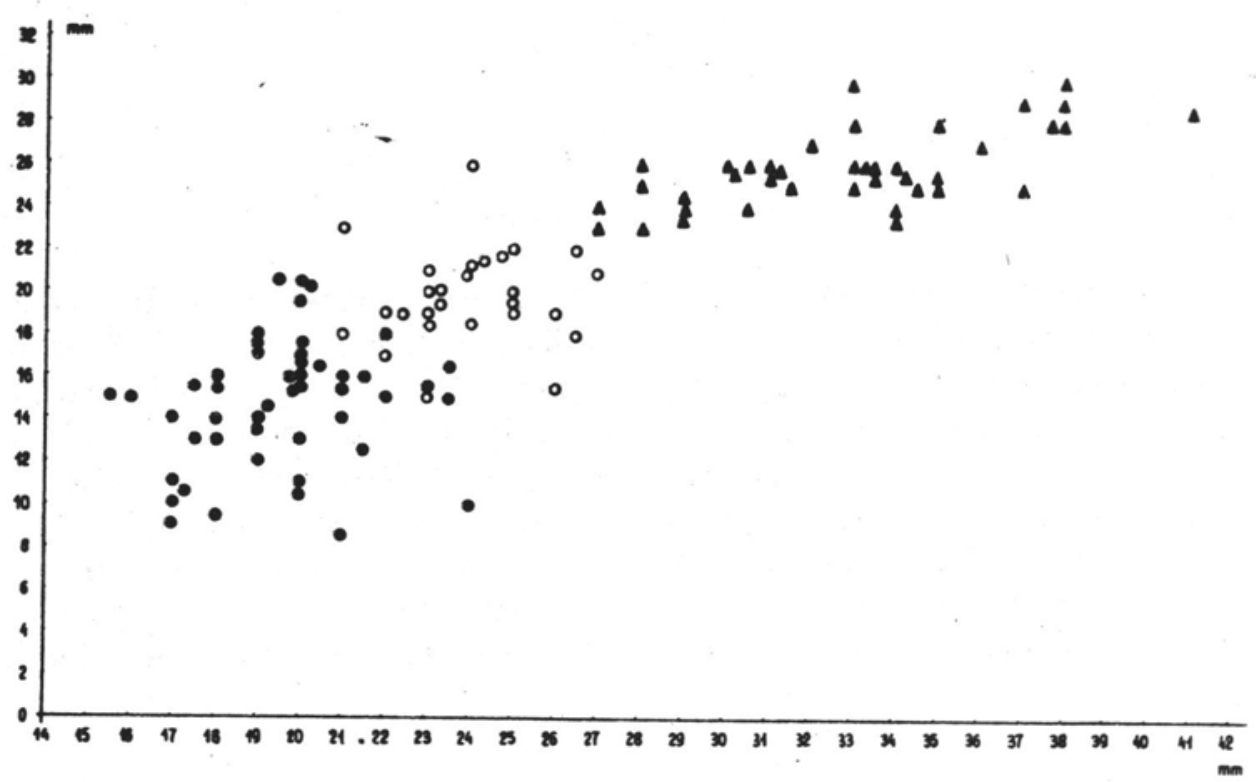

Fig. 2. Scatter diagram of the investigated spectimes, based on length of pistil style (vertical axis) and length of flowers (horizontal axis). 1-Gladiolus felicis var. felicis; $2-G$. felicis ar. żmudae; $3-G$.' imbricatus

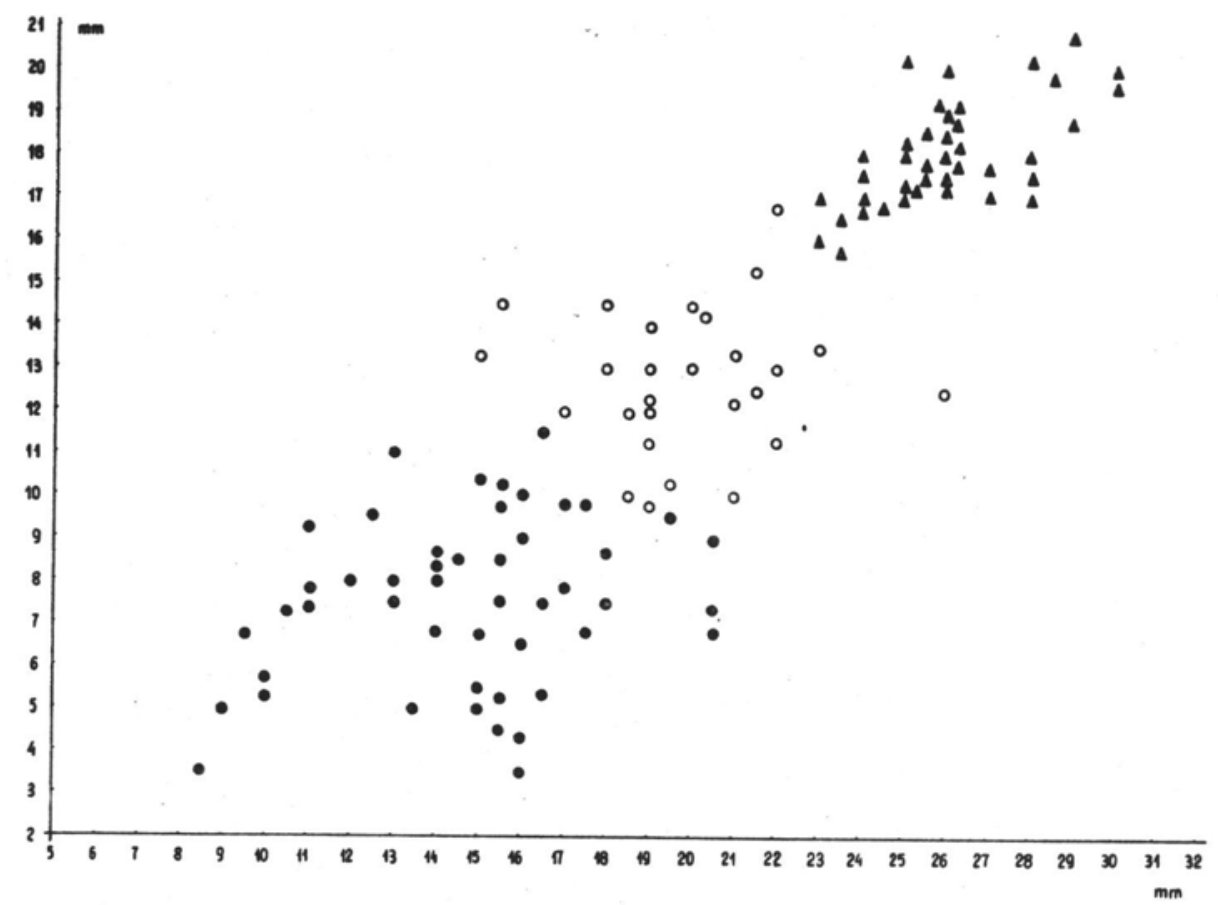

Fig. 3. Scatter diagram of the investigated specimens, based on length of filaments (vertical axis) and length of pistil style (horizontal axis). $1-$ Gladiolus felicis var. felicis; $2-G$. felicis var. imudae; $3-G$. imbricatus 
must be replaced by a new one. The name Gladiolus felicis nom. novum - formed from the name of Feliks Berdau, who described this taxon, seems appropriate.

The variability of Gladiolus felicis $(=G$. parviflorus Berdau) had not been clearly determined either by Berdau 1859) or any of the subsequent authors, and the variability itself of the species has not been studied until now.

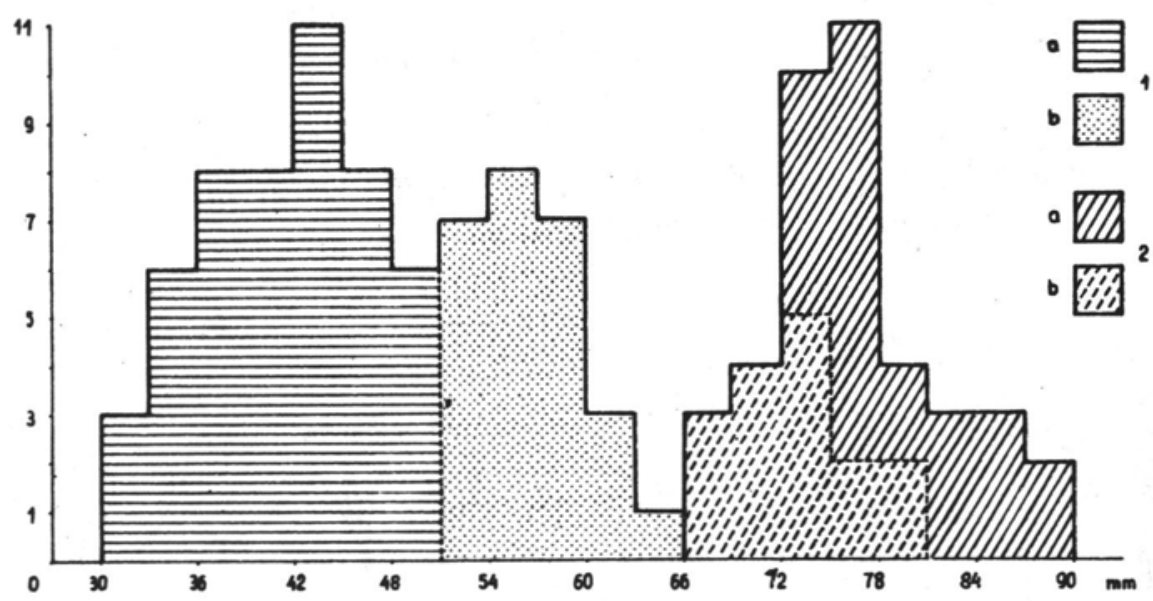

Fig. 4. Histogram illustrating the variation of the investigated specimens. Vertical axis number of specimens; horizontal axis - sum of the length of filament (mean), pistil style and flower, 1-Gladiolus felicis; a - var. felicis, b-var. imudae; 2-G. imbricatus: a - specimens from Kraków, b-specimens from the other localities

Based on the picture of variability found in this study, the morphological boundary between $G$. felicis and $G$. imbricatus was accepted as the area of the most pronounced discontinuity found in the studied material in relation to a few of the traits correlated with each other (Fig. 4). With the boundary so determined, the variability range of $G$. felicis is described by a frequency curve in which, in respect to almost all of the studied characters, two more or less distinct peaks show up. This indicates the existence of two or more separate forms within the species so discerned. However, because the hiatus between them is not sharp and both of them are found together in the same stands, they have been assigned the rank of varieties. The first one, var. felicis, encompasses the typical variability of the species, the second however, includes specimens relating somewhat to G. imbricatus. Given below is the diagnosis of $G$. felicis as accepted here and the diagnosis of its two varieties.

Gladiolus felicis Mirek, nom, novum 
Synon.: Gladiolus parviflorus Berdau 1859, Fl. Cracov.: 341, nom. illeg.

Diagnoseos supplementum: Inflorescentia heteromalla vel indistincte secunda. Perianthi lobi (tepala) margine rubescenti-lilacini, parte centrali lutescenti-viriduli. Flores axi inflorescentiae appressi, (15-(17-25)-27) mm longi. Perianthi tubus rectus vel leviter curvatus, 3-7 $\mathrm{mm}$ longus. Filamenta $3-15 \mathrm{~mm}$ longa: ratio comparativa antherarum ad filamenta: (0.5-(0.6-1.5)-2.2). Stylus (absque stugmatibus) 9-22 $\mathrm{mm}$ longus: stigmata $1.5-2.5 \mathrm{~mm}$ longa.

Lectotypus: Cracovia: in partis circa Lagiewniki prope laterariam vaporariam. Jun. 1859, leg. F. Berdau, KRAM 70616.

Speciei variabilitas

- var,felicis: flores (15-(17-22)-23.5) mm longi; perianthi tubus 3-4.5 mm longus; filamenta 3-10 (-11) mm longa: stylus (absque stigmatibus) 9-18 mm longus

- var. żmudae Mirek, var, nova: flores (21-(23-25)-27) $\mathrm{mm}$ longi; perianthi tubus 4.5-7.0 (-7.5) mm longus; filamenta (10-(11-15)-16) $\mathrm{mm}$ longa; stylus (absque stigmatibus) $18-22 \mathrm{~mm}$ longus
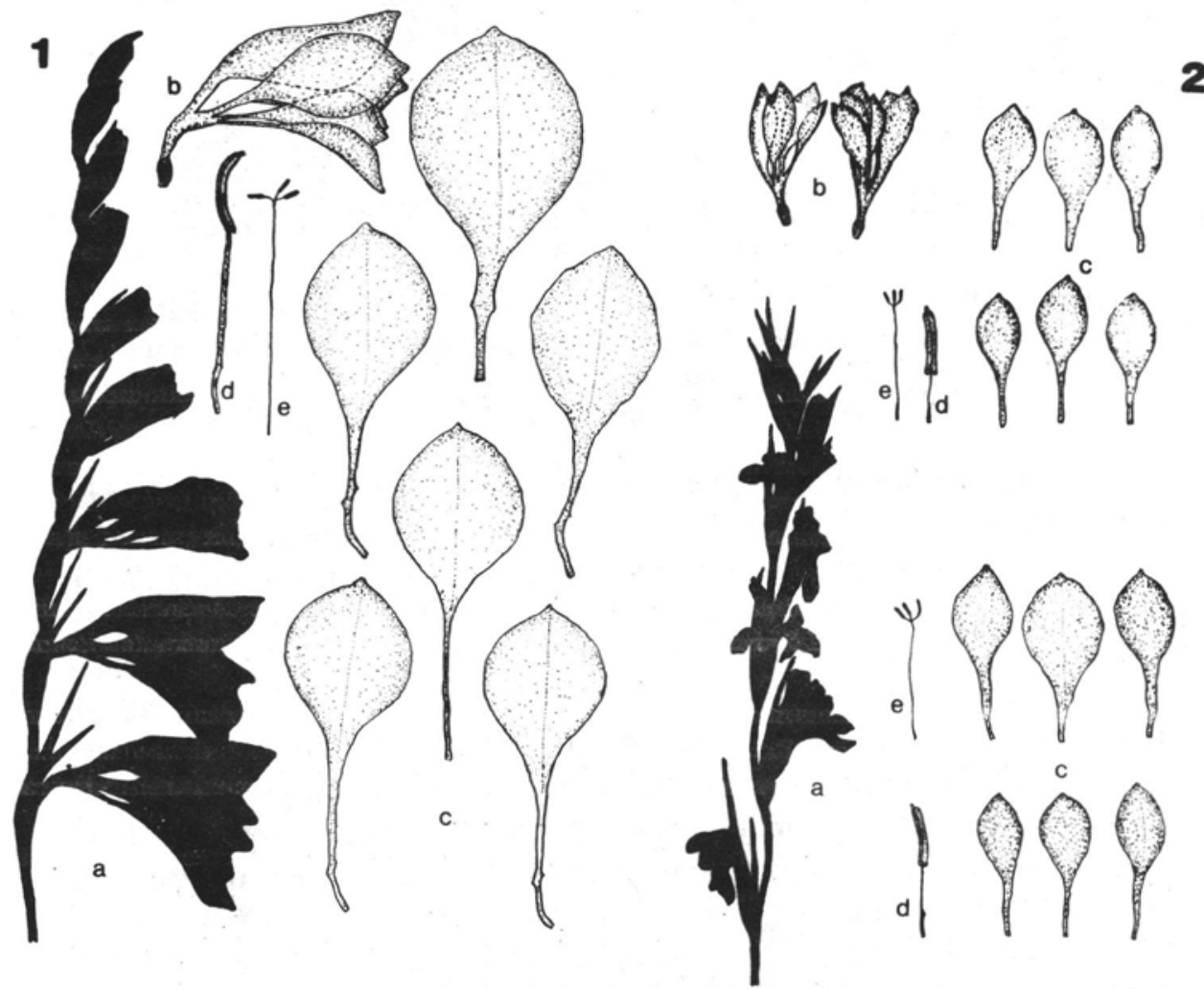

Fig. 5. Morphological details of the Gladiolus felicis Mirek var. felicis and G. imbricatus L. $\mathrm{a}$ - silhouette of an inflorescence, b - flower, c - perianth segments, d-stamen, e - style 
Attention: the name of this variety is derived from the name of Antoni Żmuda, an autstanding Polish taxonomist and investigator of Cracow flora.

CRITICAL COMMENTS

It should be noted that it is possible to narrow the range of the species G. felicis and limit it only to the typical variety, var. felicis. Forms classified as var. zmudae would in this case be treated as intermediate (most likely of hybrid descent) between the narrowly viewed G. felicis and $G$. imbricatus. Such a solution was rejected here for the following reasons:

- the group of specimens classified as var. zmudae is not exactly intermediate, but clearly refers to the typical $G$. felicis (see the histogram Fig. 4),

- it was not possible to establish with certainty the hybrid nature of the herbarium specimens classified as var. żmudae.

It should however be mentioned that the $G$. felicis specimens which most closely resembled $G$. imbricatus were treated by Żmuda (1920) as hybrids between $G$. imbricatus and $G$. parviflorus (sensu Berdau) and called $G$. x berdaui (nomen nudum - without a description and indication of type).

Taking into account the existence of forms of a more or less intermediate character (although usually resembling closely one or the other species), and the frequent finding of both species on the same stands, their crossing is quite probable. Also the fact that the G. imbricatus specimens most closely resembling $G$. felicis are exclusively from Cracow stands (Fig. 4) where both of these species have been found jointly, seems to speak in favour of their hybrid nature. Of course, they do not necessarily need to be first generation hydrids, but could be, for example, introgressive forms. The definite elucidation of the nature of the specimens classified as var. imudae (and also of a few of the $G$. imbricatus specimens most closely resembling them) can only be carried out experimentally on living material.

Unfortunately, everything seems to indicate that $G$. felicis has become

extinct on its few stands due to the destruction of its biotopestherefore the resolution of this problem in the future seems unlikely. If it were to be found however, that the specimens belonging to var. żmudae do in fact represent first generation hybrids between $G$. imbricatus and G. felicis, then the range of variability of the latter should be limited to the typical variety. This would however not change in any way the fact established during this study, that G. felicis is clearly distinct from G. imbricatus. 
The few Gladiolus felicis stands in Poland known until now are grouped in the southern part of the country. Their distribution is given on Fig. 6. Two stands outside of Poland are found close to our borders: one in the vicinity of Vilnus (Lithuanian S.S.R.) and the second near Jabłonków

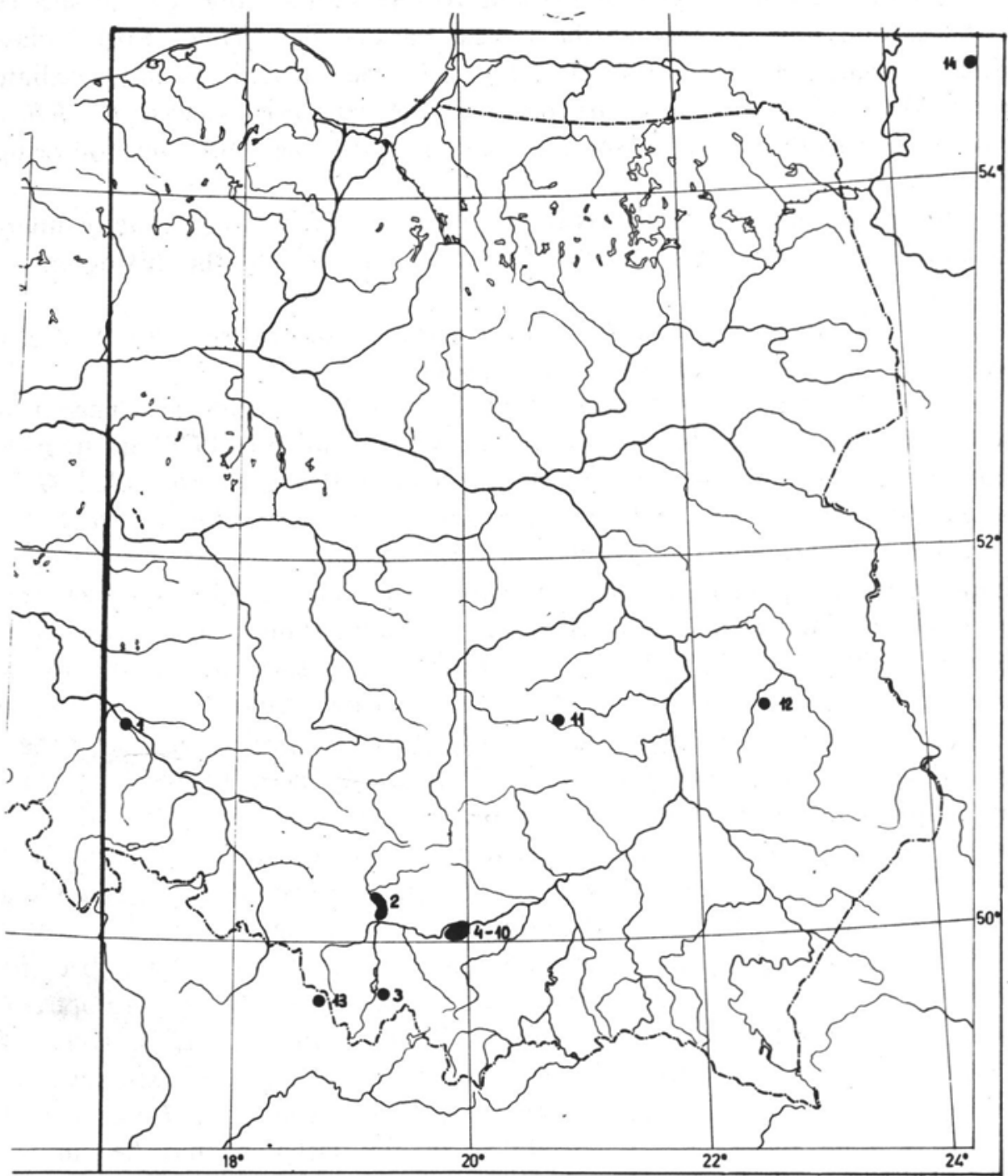

Fig. 6. Known localities of Gladiolus felicis Mirek in Poland and in adjacent territories. Numbers of the localities (1-14) correspond to those given in the text 
in Czechoslovakia. A list of the hitherto known stands is given below. The numbers of the stands correspond to the numbers on the map (Fig. 6). Stands described in literature or on herbarium labels in different ways, but representing in reality the same locality, are listed under the same number. For each stand, the herbarium documentation (if such exists) is given first, next, the literature references mentioning the stand.

1 - Wrockaw (Hauffener Wiesen) (Schube 1903).

2 - Between Podłęże, Jeleń, Dąb and Chełmek on the Przemsza River (Rehmann 1868 a, b).

3 - Western Carpathians, Pewel Mała near Żywiec, 1926, coll.? KRA (not numbered).

4 - Cracow: ca. Zagórze (Berdau 1859).

5 - Cracow: Kobierzyn, 1909, coll. A. Żmuda, KRAM, 42355; Cracow: Zakrzówek-Kobierzyn, 1909, coll. A. Żmuda, KRAM 42359; (Berdau 1859, Żmuda 1920).

6-Cracow: Borek Fałęcki, 1859, coll. F. Berdau, KRAM 70615, 70616, 70617; (Berdau 1859).

7 - Cracow: ca. Lagiewniki, 1859, coll. F. Berdau, KRAM 70613, 70616 a-h; KRA (not numbered), with no data and name of collector; (Berdau 1859).

8 - Cracow: ca. Zakrzówek, 1859, coll. F. Berdau, KRA (not numbered); (Berdau 1859).

- Cracow: Kapelanka (in Zakrzówek), 1909, coll. A. Żmuda, KRAM 42364, (Żmuda 1920).

- Cracow: Zakrzówek, between Kapelanka, Pychowice and Kobierzyn, 215 m a.s.1., 1909, coll. A. Żmuda, KRAM 42356, 42357, 42358, 42361, 70629, 1914, coll A. Żmuda, KRAM 42360, 42361, 42362; (Żmuda 1920).

9-Cracow: ca. Ludwinów (Berdau 1859).

10 - Cracow: Swoszowice, (Zapałowicz 1906 - on the basis of a specimen collected by Jabłoński in 1886).

11 - Holy Cross Mts. Świnia Góra Reserve, 1965, coll H. Piękoś, KRAM 58487 (one specimen on a sheet with Gladiolus imbricatus L.).

12 - Domináw near Lublin (Fijałkowski 1960).

Adjacent territories

13 - Czechoslovakia: Vicinity of Jabłonków; Głuchowa near Nydek (Schube 1903).

14 - Lithuanian S.S.R.: Vicinity of Vilnus: Bonifacowo near Sół, 1937, coll. P. Wiśniewski, KRAM 75811. 
Acknowledgement

The author would like to express his gratitude to Dr. T. Tacik for his help in translating the Latin diagnoses.

\section{REFERENCES}

Berdau F., 1859. Flora Cracoviensis. Cracoviae, p. 448.

Fijałk owski D., 1960. Wykaz rzadszych roślin Lubelszczyzny. Część IV. Fragm. Flor. Geobot. 6: 261-286.

Hamilton A. P., 1980. Genus Gladiolus L. In: Flora Europaea. Tutin T.G. et al. (eds.), vol. 5., Cambridge Univ. Press, Cambridge. pp. 101-102.

Holmgren P. K., Keuken W., Schofield B. K., 1981. Index herbariorum. Part I. The herbaria of the world. Reg. Veg. 106: 1-450.

Index Kewensis, 1895, vol. 1., Clarendon Press, Oxford. p. 1031.

Kulczyński S., 1919. Gladiolus L. In: Flora Polska. Raciborski M., Szafer W. (eds.), vol. 1. PWN, Kraków. pp. 146-148.

Nyman C. F., 1878-1882. Conspectus Florae Europaeae. Örebro, p. 1046.

Rehmann A., 1868a. Sprawozdanie z wycieczki botanicznej w zachodnią część Galicyi. Spraw. Komis. Fizjogr.

Rehmann A., 1868b. Botanische Fragmente aus Galizien. Verhandl. d.k.k. zoolog.-bot. Gesellschaften in Vien.

Schube Th., 1903. Die Verbreitung der Gefässpflanzen in Schlesien. Druck von R. Nischkovsky, Breslau. p. 362.

Szafer W., Kulczyński S., Pawłowski B., 1953. Rośliny Polskie. PWN, Warszawa. pp. XXVIII, 1020.

Zapałowicz H., 1906. Krytyczny przegląd roślinności Galicyi. Nakł. Akad. Umiejętn. Kraków p. 246.

Żmuda A., 1920. Rzadsze lub nowe rośliny flory krakowskiej. Spraw. Komis. Fizjogr. 53-54: 30-76.

\section{Studia nad endemitami Polski - rośliny naczyniowe. 1. Gladiolus felicis Mirek (Iridaceae)}

\section{Streszczenie}

W pracy rozważany jest status taksonomiczny oraz nomenklatura Gladiolus parviflorus Berdau. Takson ten opisany $z$ terenu Krakowa (Berdau 1859) uchodził za endemit flory Polski. Jego odrębność była jednak od początku kwestionowana tak przez polskich, jak i zagranicznych botaników. Zwykle uważano ten takson za konspecyficzny z Gladiolus imbricatus L. (Nyman 1878-82, Hamilt on 1980). Na podstawie przeprowadzonych badań biometrycznych na materiale zielnikowym, potwierdzono pierwotną opinię Berdaua (1859) o wyraźnej odrębności $G$. parviflorus w stosunku do $G$. imbricatus (por. rys. 1, 2, 3, i 4). Ważniejsze różnice między tymi gatunkami zestawiono $w$ tabeli 1 oraz na rysunku 5 . W związku $\mathrm{z}$ istnieniem wcześniejszych homonimów, nazwę G. parviflorus jako nieważną, zastąpiono nową: Gladiolus felicis (od imienia Feliksa Berdaua, który wyróżnił 
ten takson). W obrębie G. felicis wyróżniono dwie odmiany, tj. typową var. felicis oraz drugą var. żmudae. Ta ostatnia obejmuje okazy odbiegające od typu w kierunku G. imbricatus. Zestawiono wszystkie znane dotychczas stanowiska G. felicis (patrz wykaz stanowisk), a ich rozmieszczenie przedstawiono na mapie (ryc. 6). Praca nie rozwiązuje wszystkich problemów związanych z G. felicis. Òtwarty pozostaje np. problem jego genezy. Do rozwiązania tej kwestii konieczny jest jednak żywy materiał. Niestety, dotychczasowe poszukiwania nie przyniosły rezultatów i wszystko wskazuje na to, że gatunek ten wyginął zupełnie na swych stanowiskach, wskutek antropogenicznych zmian jego biotopów. 